\title{
ONLINE SOCIATRIC PRACTICES: NEW STUDIES AND EXPERIENCES
}

\section{PRÁTICAS SOCIÁTRICAS ON-LINE: NOVOS ESTUDOS E EXPERIÊNCIAS PRÁCTICAS SOCIÁTRICAS ON-LINE: NUEVOS ESTUDIOS Y EXPERIENCIAS Aline Oliveira Belém¹,* (ID , Maria da Penha Nery² (D)}

The Revista Brasileira de Psicodrama (RBP) has published several articles on Psychodrama online for the past two years, which contribute to our reflections and professional practices. This RBP issue seeks to complement this repertoire and focuses on the studies of psychodramatists on their experiences and strategies in social practice in virtual environments.

The authors of this issue point out some vicissitudes of this practice and present its consequences on the participants' lives. Such experiences are the result of experiencing, in Brazil and the world, the pandemic of Covid-19 and, as a result, we need to immerse ourselves in online care, using the various methods of action, among them: bipersonal psychodrama, psychodramatic group psychotherapy, psychodrama with children, educational psychodrama, sociodramas, sociopsychodramas, Spontaneous Theaters, and in training and improvement courses in the area.

The historical context of the pandemic provides intense personal and collective suffering. It occurs at a time when virtuality is intensifying, establishing relationships through social networks, the internet, digital technologies and virtual environments. This context brings an agonizing transition between the new and the old, such as constructing our subjectivities, in the work processes, in the leisure experiences, in human relationships and social life.

According to Bauman (2001), we live in liquid modernity, in which people create fragile interactions with a low tolerance for divergences and differences. Liquid relationships, associated with virtual relationships, have a high degree of connection and disconnection, reconstructing subjectivity, the culture of consumption, and the massification of technologies. Human and affective ties are fleeting, appear and fall apart at speed in response to rapidly changing tasks. For the author, in virtual interactions, people build an imaginary reality, or an aestheticization of reality, to supply internal absences.

In this social context, psychodramatists assume a role in performing psychotherapies and sociotherapies through the virtual environment, following Moreno's creativity of working with the technologies of his time (Moreno, 1984). In virtual consultations, psychodramatists welcome the pain of the sessions' participants, support the sufferings, help in the manifestation of spontaneity-creativity and treat the symptoms of people and groups in a pandemic in the liquid and digital society.

As for online care, Fleury (2020) presents some ethical arguments in favor of the work of telepsychology or telepsychodrama, such as the fact that remote care expands possibilities when considering reach to more distant regions (such as rural areas), to people who are foreigners in the countries where they live, in addition to the economic advantages. However, since March 2020, the main motivation for large-scale remote care has been the pandemic of Covid-19.

In the digital environment, calls can be made synchronously, when participants are connected in real-time, using telecalls and video calls; or asynchronously, when the interaction between the interlocutors occurs at different times, often minimizing problems with an internet connection (Meyer \& Prado, 2006). E-mails can be used, and messages can be exchanged by chat applications, such as WhatsApp and Telegram, or exchanged recorded audio.

In online sociatric practice, the Federal Council of Psychology's ethical determinations is followed (CFP Resolution No.11,2018). Professionals carry out technical and electronic adjustments to improve handling in the virtual environment, observe logistical factors that guarantee confidentiality and emotional factors that favor therapeutic continence, with the security and confidence necessary to work. 
We can say that we initially focused more on the limitations than on the potential of online service. Weinberg (2021), when talking about online group psychotherapy, states that it is impossible to compensate for all the limitations of remote care (such as the lack of body contact) and states that it has more advantages than disadvantages, especially during the pandemic. Also, the author shows us that it is possible to develop a solid therapeutic alliance in online care, even though it may take a little longer to establish itself, compared to its development in face-to-face care.

At first, when the need for social isolation for the whole world arose, the thinking of many psychodramatists was, as mentioned in Kornienko (2020, p. 4), "I do not know how to do anything now". However, at the present time, it is observed that there was an accumulation of rich experiences in virtual care to the point that it becomes possible to affirm that, yes, we have advanced and matured a lot as psychodramatists.

Kornienko (2020), in his work with online groups, presented contributions, such as the improvement of the handling with the equipment; the need for a firmer and more explicit expression on the part of the director; offering support for group members to react to each other, including with the physical expression of emotions. These conclusions are related to the concept of warm-up and its maintenance, now in the virtual environment.

Ramalho (2020), when talking about online individual psychodrama, points out some examples, among them: request for positioning the camera of both (therapist and client) to perform body warm-up; the use of intermediate objects to represent characters or elements of the scene; expression through the hands; request for drawings of the scenes made by the client. The author presents action strategies for online care: the internalized dramatization and the interview on paper, and the use of action techniques: role reversal, double, mirror and soliloquy.

Armañanzas Ros (2020) organized a set of resources and exercises for online group Psychodrama, proposing creative adjustments, such as starting the session by saying "action!" and asking the group members to voice themselves (speaking what they think as if they were voice actors). The author uses the soliloquy technique for non-specific warm-up.

Recently, Echenique (2021) organized the book Psicodrama Virtual (Virtual Psychodrama). In this book, a group of psychodramatists reports their experiences with virtual or remote assistance. Professionals show us the path of spontaneity for the development of creativity, sharing affections and knowledge.

This issue presents studies of experiences that include as many fronts of action as possible with therapeutic methods of online action. There is the work of Psychodrama with children, with psychotherapeutic groups, with groups for educational purposes. There is a sociodramatic experience of a single act or multiple experiences.

We tried, in this issue, to contribute theoretically and technically to our professional activities. However, there is a need for in-depth studies. It is necessary to know and create more about, for example, virtuality, virtual reality and its connections with Psychodrama, specifics of online service with action methods, differences between virtual and face-to-face service and the effectiveness of online methods.

\section{REFERENCES}

Armañanzas Ros, G. (2020). Recursos e Ejercicios de Terapia de Grupo y Psicodrama Online. Grupos Escuela de Psicodrama. Bauman, Z. (2001). Modernidade líquida. Zahar.

Echenique, M. (Org.). (2021). Psicodrama virtual: Explorando a toca do coelho. Araucária.

Fleury. H.J. (2020). Psicodrama e as especificidades da psicoterapia on-line. Revista Brasileira de Psicodrama, São Paulo, 28(1), 1-4. https://doi.org/10.15329/2318-0498.20203

Kornienko, P. (2020). Aspectos especificos sobre la conducción de grupos terapéuticos en un entorno online. https:// psychotherapy-lab.ru/wiki/pg14/es

Meyer, B. S. e Prado, O. Z. (2006). Avaliação da relação terapêutica na terapia assíncrona via internet. Psicologia em Estudo, Maringá, 11(2), 247-257. https://doi.org/10.1590/S1413-73722006000200003

Moreno, J. L. (1984). Psicodrama (3a ed., A. Cabral, Trad.). Cultrix. (Obra original publicada em 1975). 
Ramalho, C. M. R. (2020). Psicodrama a dois on-line: Desafios e especificidades. In J. P. C. de Santana et al. (Orgs.), Interfaces dos atendimentos psicológicos on-line.

Resolução CFP n. 11 (2018). Regulamenta a prestação de serviços psicológicos realizados por meios de tecnologias da informação e da comunicação e revoga a Resolução CFP n. 11/2012. Conselho Federal de Psicologia. https:// atosoficiais.com.br/lei/orientacao-psicologica-pela-internet-cfp?origin=instituicao

Weinberg, H. (2121). Obstacles, Challenges, and Benefits of Online Group Psychotherapy. American Journal of Psychotherapy in Advance. https://doi.org/10.1176/appi.psychotherapy.20200034 